\title{
EFEK PEMAKAIAN KONTRAS UNTUK OPTIMALISASI CITRA PADA PEMERIKSAAN DIAGNOSTIK MAGNETIC RESONANCE IMAGING (MRI)
}

\author{
Agus Wahyu Jatmiko ${ }^{1}$, Chendra Arum Wandani ${ }^{2 *}$, Linda Wahyu Istigfarisky ${ }^{2}$ \\ ${ }^{1}$ Instalasi Eadiologi RSUD Saiful Anwar Malang, Indonesia \\ ${ }^{2}$ Departemen Fisika, Fakultas Sains dan Teknologi, Universitas Airlangga \\ Surabaya, Indonesia 60115 \\ e-mail: 1koko_awj@yahoo.co.id, *2chen.arum.wandani-2017@fst.unair.ac.id, \\ ${ }^{2}$ linda.wahyu.istigfarisky-2017@fst.unair.ac.id
}

\begin{abstract}
Abstrak
Magnetic Resonance Imaging (MRI) merupakan suatu alat diagnostik mutakhir untuk memeriksa dan mendeteksi tubuh anda dengan menggunakan medan magnet yang besar dan gelombang frekuensi radio, tanpa menggunakan sinar $\mathrm{X}$, ataupun bahan radioaktif sehingga MRI sangat aman. Pemberian Kontras dalam pemeriksaan MRI diperlukan untuk emmberikan gambaran hasil dari pemeriksaan yang lebih jelas, sehingga mempermudah dilakukannya diagnostic terhadap pasien. Kontras digunakan sebagai perbandingan antara T1 (anatomi) dan T2 (patologi) yang selanjutnya dapat digunakan sebagai penentu apakah pasien tersebut memiliki kelainan (struktur abnormal). Kontras akan segera meningkat setelah di injeksi tergantung pada urutan pulsa dan protokol yang digunakan. Biasanya dapat di amati pada waktu maksimal 5 menit tergantung pada jenis lesi/jaringan.
\end{abstract}

Kata kunci-MRI, Kontras, T1, T2, health service 


\section{ABSTRACT}

Magnetic resonance imaging (mri) is a state-of-the-art diagnostic tool to examine and detect your body using a large magnetic field and radio frequency waves, without the use of x-rays or radioactive materials so that mri is very safe. giving contrast in mri examination is needed to provide a clearer picture of the results of the examination, making it easier to carry out diagnostics for patients. Contrast is used as a comparison between $\mathrm{t} 1$ (anatomy) and $\mathrm{t} 2$ (pathology) which can then be used to determine whether the patient has an abnormality (structural abnormality). contrast will increase immediately after injection depending on the pulse sequence and the protocol used. Usually observable in a maximum of 5 minutes depending on the type of lesion/tissue.

Keyword: mri, contrast, $\mathrm{t} 1, \mathrm{t} 2$, health service 


\section{PENDAHULUAN}

Kemajuan teknologi saat ini, terutama pada bidang kesehatan telah memberikan banyak manfaat kepada masyarakat sekitar dan memberikan kemudahan bagi para praktisi kesehatan untuk mendiagnosa penyakit serta menentukan jenis pengobatan bagi pasien. Salah satu bentuk kemajuan tersebut adalah penggunaan alat MRI (Magnetic Resonance Imaging) untuk melakukan pencitraan diagnosa penyakit pasien untuk meningkatkan pelayanan kesehatan pada masyarakat.

Magnetic Resonance Imaging (MRI) merupakan suatu alat diagnostik mutakhir untuk memeriksa dan mendeteksi tubuh anda dengan menggunakan medan magnet yang besar dan gelombang frekuensi radio, tanpa menggunakan sinar $\mathrm{X}$, ataupun bahan radioaktif sehingga MRI sangat aman di gunakan pada berbagai kalangan termasuk balita namun tida disarankan untuk wanita yang hamil muda.

MRI menciptakan gambar yang dapat menunjukkan perbedaan sangat jelas dan lebih sensitif untuk menilai anatomi jaringan lunak dalam tubuh dibandingkan dengan pemeriksaan menggunakan X-ray maupun CT scan. Organ yang dapat di foto menggunakan MRI terutama otak, sumsum tulang belakang, susunan saraf (Muzamil et al, 2018). Juga jaringan lunak dalam susunan musculoskeletal seperti otot, ligament, tendon, tulang rawan, ruang sendi seperti misalnya pada cedera lutut maupun cedera sendi bahu. Pemeriksaan lain yang dapat dilakukan dengan MRI yaitu evaluasi anatomi dan kelainan dalam rongga dada, payudara, organ organ dalam perut,

Pencitraan resonansi magnetik (MRI) ditemukan pada tahun 1970, oleh Paul C Lauterbur dan Stony Brook di New York. MRI menggunakan frekuensi radio (RF) dan gradien medan magnet spasial untuk menghasilkan gambar yang menampilkan sifat magnetik proton, yang mencerminkan informasi yang relevan secara klinis. Pada dasarnya, ini adalah teknik resonansi magnetik nuklir (NMR) yang diterapkan untuk pencitraan manusia. Pada tahun 2003 mendapatkan Hadiah Nobel dalam bidang kedokteran dianugerahi untuk penemuan di atas, yang dibagikan oleh Sir Peter Mansfield, dan Paul C Lauterbur.

Nuclear magnetic resonance (NMR) adalah studi spektroskopi dari sifat magnetik inti atom (1940). Proton dan neutron dari nukleus memiliki medan magnet yang terkait dengan spin nuklir dan distribusi muatannya (Muzamil et al, 2021). Resonansi adalah penggabungan energi yang menyebabkan inti individu, ketika ditempatkan dalam medan magnet luar yang kuat, menyerap secara selektif, dan kemudian melepaskan, energi yang unik untuk inti tersebut dan lingkungannya.

\section{Kontras Gambar (image contrast)}

Gambar MR terdiri dari tiga sifat jaringan, yaitu, PD , T1, dan T2. Sedangkan TE, TR adalah parameter mesin, yang menimbang kontras dalam gambar. 
Jurnal Biosains Pascasarjana Vol. 23 (2021) pp

(C) (2021) Sekolah Pascasarjana Universitas Airlangga, Indonesia

Kecerahan piksel tergantung pada (i) kerapatan proton, (ii) pemulihan $\mathrm{Mz}$ (panjang T1, dibandingkan dengan TR), dan (iii) peluruhan Mxy, (panjang $\mathrm{T} 2$, dibandingkan dengan TE). Pemilihan TR dan TE sangat penting, sehingga kecerahan gambar tergantung pada salah satu dari parameter jaringan T1, T2, PD. Gambar dapat diperoleh sebagai gambar berbobot $\mathrm{T} 1$, atau gambar berbobot $\mathrm{T} 2$ dan atau gambar berbobot kerapatan proton.

\section{T1 Weighted Image}

Gambar $\mathrm{T} 1$ kontras

menghasilkan jaringan

karakteristik T1 dengan menghilangkan T2. Ini mempekerjakan TR pendek, (300-800 ms) untuk memaksimalkan kontras dan TE pendek, (15 ms) untuk meminimalkan ketergantungan T2. Kontras gambar disebabkan oleh properti pemulihan $\mathrm{T} 1$ dan lebih pendek $\mathrm{T} 1$, lebih terang gambar. Di otak, jaringan otak, lemak, materi putih, materi abu-abu, dan CSF dibedakan dengan baik dalam gambar T1 tertimbang (Gambar 1). Lemak paling pekat dan tampak putih, tetapi sinyal CSF terendah dan tampak hitam
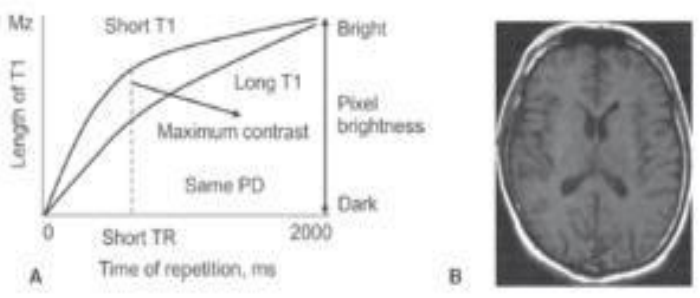

Gambar 1. A. T1 pada berbagai TR, maksumam kontras pada TR pendek dan PD konstan, B. Gambar Otak, TR=500 ms, $\mathrm{TE}=8 \mathrm{~ms}$

\section{T2 Weighted Image}

Gambar T2 weighted menghasilkan kontras berdasarkan karakteristik jaringan T2, dengan menekankan T1. Ini mempekerjakan TR panjang (1000-2000 ms) untuk mengurangi kontras T1 dan TE panjang (90$140 \mathrm{~ms}$ ), untuk memaksimalkan kontras T2. Kontras gambar disebabkan oleh properti pemulihan T2, dan lebih lama T2, lebih terang sinyalnya. Dalam citra otak T2 yang tertimbang, CSF lebih terang daripada Lemak (Gambar 2).
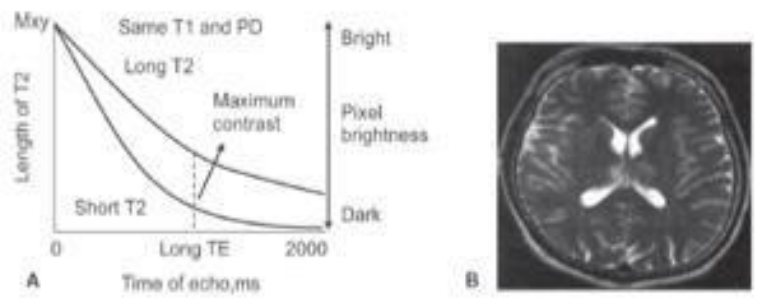

Gambar 1. A. T2 pada berbagai TE, TE memberi maksimum kontras pada TR1 dan PD konstan, B. Gambar Otak, TR=2400 ms, $\mathrm{TE}=90 \mathrm{~ms}$

Proton Density Weighted Image Bobot kerapatan spin terutama bergantung pada perbedaan jumlah proton per cc. Semakin besar kepadatan putaran, semakin besar magnetisasi longitudinal (mis. Lipid, lemak). Ini mempekerjakan TR panjang (1000-3000 ms), untuk meminimalkan kontras $\mathrm{T} 1$ dan TE pendek (15 ms), untuk meminimalkan efek T2. Kekuatan sinyal lebih besar dengan lebih sedikit noise. Semakin tinggi PD, semakin cerah gambarnya, dan karenanya CSF tampak putih, tetapi materi putih 
(C) (2021) Sekolah Pascasarjana Universitas Airlangga, Indonesia

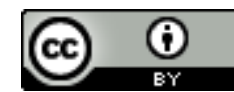
tampak hitam (Muzamil et al, 2021). potongan penampang tubuh manusia. Meskipun rasio sinyal terhadap noise (SNR) lebih tinggi, kontras gambarnya buruk (Gambar 3).

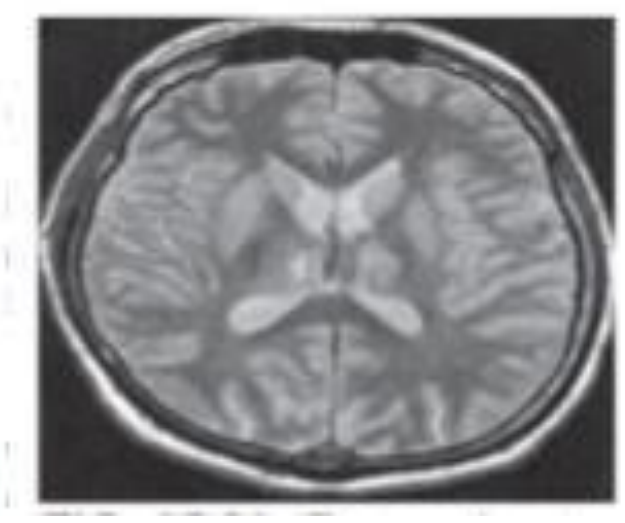

Gambar 3. Gambar otak pada TR=2400 ms dan $\mathrm{TE}=30 \mathrm{~ms}$

\section{METODE PENELITIAN}

Penelitian ini menggunakan dua metode, yaitu: Observasi Langsung dan Wawancara. Dalam metode observasi langsung dilakukan dengan cara mengikuti langsung praktik kegiatan pemeriksaan MRI pada ruangan MRI yang ada di RSUD Dr Saiful Anwar Malang. Sedangkan metode wawancara dilakukan dengan cara mendiskusikan dan menanyakan langsung kepada fisika medis yang bekerja di RSUD Dr Saiful Anwar mengenai prinsip kerja serta pemberian kontras pada MRI.

\section{HASIL DAN PEMBAHASAN}

MRI (Magnetic Resonance Imaging) adalah sebuah alat diagnostic imaging tinggi yang menggunakan medan magnet, frekuensi radio tertentu dan seperangkat computer untuk menghasilkan gambar potongan-
Gambar diperoleh dari hasil interaksi antara molekul sel tubuh dan signal yang dipancarkan oleh frekuensi radio sedemikian rupa sehingga menghasilkan data yang dapat diolah computer menjadi imaging (gambar) yang kemudian dicetak dalam bentuk foto. Tubuh manusia memiliki $70 \%$ air dan hydrogen berlimpah. Inti hydrogen terdiri dari proton dan neutron. Mereka berputar terus menerus seperti gasing. Putaran dan distribusi muatannya memberikan sifat magnetis, sehingga proton saling meniadakan maka medan magnetnya bernilai 0 (Astuti et al, 2017).

Proses terbentuknya citra MRI dapat digambarkan sebagai berikut: Bila tubuh pasien diposisikan dalam medan magnet yang kuat, inti-inti hidrogen tubuh akan searah dan berotasi mengelilingi arah/vektor medan magnet (Gambar 4).

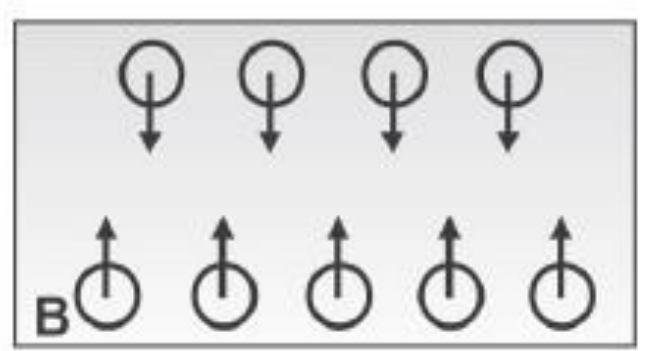

Gambar 4. posisi inti hydrogen ketika terkena magnet

Bila signal frekuensi radio dipancarkan melalui tubuh (proses presesi), beberapa inti hidrogen akan 

menyerap energi dari frekuensi radio tersebut dan mengubah arah, atau dengan kata lain mengadakan resonansi. Bila signal frekuensi radio dihentikan pancarannya, inti-inti tersebut akan kembali pada posisi semula, melepaskan energi yang telah diserap dan menimbulkan signal yang ditangkap oleh antena dan kemudian diproses computer dalam bentuk radiograf. Jadi dari awalnya energi yang didapat dari RF, dan RF di stop, kemudian dilemparkan lagi saat proses relaksasi, dilepas dan ditangkap oleh antenna koil yang terpasang pada pasien dan diproses dengan gradient koil menggunakan Transformasi Fourier hingga menjadi sebuah gambar pada komputer.

Instrumen MRI meliputi, Magnet utama merupakan magnet yang menghasilkan medan magnet yang paling besar pada mesin MRI. Magnet utama dipakai untuk membangkitkan medan magnet berkekuatan besar yang mampu menginduksi jaringan tubuh sehingga menimbulkan magnetisasi. Besar medan magnet tersebut sesuai dengan rentang medan magnet yang digunakan untuk diagnosis yaitu antara 0,1 - 3,0 Tesla. Apabila nilai medan magnet (B) besar maka energi yang dihasilkan juga akan besar. Sehingga sinyal yang ditangkap oleh gradien koil semakin baik dan menghasilkan gambar yang jelas. Pesawat MRI yang yang digunakan dalam penelitian ini adalah magnet superkonduktif dengan merk philips dengan kekuatan medan magnet 3.0 T dan $1.5 \mathrm{~T}$ sehingga hasil gambar dari MRI $3.0 \mathrm{~T}$ resolusinya lebih baik daripada hasil gambar dari MRI 1.5 T.

Magnet tersebut juga dililiti kawat tembaga dan dialiri arus listrik. Penggunaan Cyrogen berupa Helium cair yang terdapat dalam pesawat MRI digunakan untuk menjaga sifat kemagjaringan. Hal ini karena Helium bersuhu \pm - 200oC, dan untuk menjaga sifat kemagnetan dibutuhkan suhu yang dingin. Penggunaan Cryogen dapat membuat resistensi pada kawat menjadi nol, sehingga arus dapat dinaikkan dan akan menghasilkan medan magnet yang tinggi. Tetapi, ketika suhu Cyrogen naik hingga titik didih Helium secara bersamaan, maka keduanya akan menguap menjadi gas. Proses tersebut dinamakan "quenching". Proses ini berbahaya bagi medan magnet. Keuntungan lain dari magnet superkonduktor adalah homogenitas medan magnet yang tinggi (Blink, 2004).

Kualitas gambar MRI tergantung pada rasio sinyal terhadap noise (SNR) dari sinyal yang diperoleh dari pasien. Beberapa kumparan pencitraan MR 
diperlukan untuk menangani keragaman aplikasi. Kumparan besar memiliki bidang pengukuran besar, tetapi intensitas sinyal rendah dan sebaliknya (lihat juga diameter kumparan ). Semakin dekat koil ke objek, semakin kuat sinyal - semakin kecil volumenya, semakin tinggi SNR .

SNR sangat penting dalam memperoleh gambar tubuh manusia yang jelas. Bentuk koil tergantung pada pengambilan sampel gambar. Homogenitas terbaik yang tersedia dapat dicapai dengan memilih jenis kumparan yang sesuai dan posisi kumparan yang benar. Orientasi sangat penting untuk sensitivitas kumparan RF dan oleh karena itu kumparan harus tegak lurus terhadap medan magnet statis. Sinyal RF berada dalam kisaran 10 hingga 100 MHz. Selama serangkaian pengukuran citra klinis, seluruh spektrum frekuensi yang diminati adalah orde $10 \mathrm{kHz}$, yang merupakan pita yang sangat sempit, mengingat frekuensi pusat sekitar 100 MHz. Ini memungkinkan penggunaan teknik pencocokan frekuensi tunggal untuk gulungan karena lebar pita bawaannya selalu melebihi lebar pita gambar. Solenoid multi belok, koil sangkar burung, solenoid belok tunggal , dan koil sadel. Dua jenis pulsa RF digunakan dalam MRI, yaitu, pulsa RF $180^{\circ}$ dan pulsa RF $90^{\circ}$. Pulsa RF $180^{\circ}$ memiliki energi total, sehingga memberikan energi yang diperlukan untuk setiap proton, yang memiringkannya $\quad 180^{\circ}, \quad$ yaitu membalikkan vektor magnet ke arah Mz. Pulsa RF $90^{\circ}$ adalah pulsa yang memiliki energi sama dengan setengah dari total energi, yang memiringkan setengah dari dipol. Dengan demikian, penerapan pulsa RF $90^{\circ}$ akan membawa jumlah proton yang sama dalam posisi putaran ke atas dan ke bawah. Mz direduksi menjadi nol dan koherensi fasa dipol menghasilkan magnet transversal, Mxy yang sama dengan memiringkan $\mathrm{Mz}$ ke $90^{\circ}$.

Kekuatan medan magnet menentukan frekuensi resonansi jaringan. Frekuensi meningkat atau menurun secara linear dengan peningkatan atau penurunan kekuatan medan magnet. Kisaran kekuatan medan magnet khas untuk pencitraan adalah 0,1 hingga 4,0 T. Dalam kasus hidrogen, frekuensi prosesi proton adalah 21.29, 42.58, 63.87 dan $127.74 \mathrm{MHz}$, masingmasing untuk kekuatan medan magnet 0.5 T, 1.0 T, 1.5 T, dan 3 T. Saat pulsa RF $90^{\circ}$ ditarik, sistem yang terganggu kembali ke keadaan setimbang. Vektor transversal terus berputar di bidang Mxy, dan menginduksi tegangan $\mathrm{AC}$ di koil 

penerima. Ini adalah sinyal MR yang disebut peluruhan induksi bebas (FID). Sinyal ini juga merupakan RF yang memiliki tegangan sesuai urutan $\mathrm{mV}$. Sinyal MR lebih besar ketika $90^{\circ} \mathrm{RF}$ dimatikan. Setelah itu, masing-masing putaran keluar dari fase, dan kembali ke orientasi aslinya. Akibatnya, Mz tumbuh dan Mxy berkurang. Oleh karena itu, sinyal MR yang diinduksi mengalami peluruhan, tetapi frekuensinya tetap sama. Dengan demikian, sinyal MR dari masing-masing voxel dapat diidentifikasi untuk menghasilkan nuansa abu-abu pada gambar akhir. Sinyal yang dihasilkan oleh pulsa 90 derajat tergantung pada $\mathrm{Mz}$ segera sebelum pulsa diterapkan. Sinyal sebanding dengan (i) kerapatan proton $\left(\mathrm{p} / \mathrm{mm}^{3}\right)$, (ii) rasio gyromagnetik inti,

(iii) kekuatan medan magnet (Bo). Hanya proton seluler yang memberikan sinyal MR, dan sebagian besar sinyal disebabkan oleh air (Zuhriyah et al, 2020). Molekul besar atau molekul terikat (tulang) tidak memberi sinyal. Udara di sinus tidak memiliki hidrogen, karenanya tampak hitam. Kepadatan Fungsi dari kontras ini adalah untuk meningkatkan ketepatan gambar. Pada MRI menggunakan dua obat kontras yaitu gadovist da nomniscan. Produk obat ini hanya untuk penggunaan diagnostik yang diberikan secara injeksi. Adapun Dosis kontras yang di berikan harus dihitung berdasarkan berat badan pasien, dan tidak boleh melebihi dosis yang dianjurkan per kilogram berat badan. Dosis yang diberikan yaitu

Dosis $=0,2 \times$ Berat Badan (Satuan:cc)

proton lebih tinggi dalam lemak daripada jaringan lunak, lebih tinggi pada materi abu-abu daripada materi putih. 
MRI yang ditingkatkan kontras

Tabel 1. Variasi waktu T1 dengan kekuatan medan magnet, untuk berbagai jaringan biologis.

\begin{tabular}{|c|c|c|}
\hline Jaringan & $\begin{array}{c}\text { T1, 0.5 } \\
\text { Tesla }\end{array}$ & $\begin{array}{c}\text { T1, 1.5 } \\
\text { Tesla }\end{array}$ \\
\hline Lemak & $210 \mathrm{~s}$ & $260 \mathrm{~s}$ \\
\hline Hati & $350 \mathrm{~s}$ & $500 \mathrm{~s}$ \\
\hline Otot & $550 \mathrm{~s}$ & $870 \mathrm{~s}$ \\
\hline Materi Putih & $500 \mathrm{~s}$ & $780 \mathrm{~s}$ \\
\hline Materi Abu-Abu & $650 \mathrm{~s}$ & $900 \mathrm{~s}$ \\
\hline $\begin{array}{c}\text { Cairan } \\
\text { serebrospinal }\end{array}$ & $1800 \mathrm{~s}$ & $2400 \mathrm{~s}$ \\
\hline
\end{tabular}

Gadovist: memiliki kepekaan 1 $\mathrm{mmol} / \mathrm{ml}$. Gadovist di indikasikan pada orang dewasa dan anak-anak dari segala usia untuk Peningkatan kontras dalam pencitraan resonansi magnetik (MRI). InstruksiuntukpenggunaanGadovistyaitu Produkiniditujukanuntuksekalipakai (Sumbat karet tidak boleh ditembus lebih dari satu kali), Produk obat ini harus diperiksa secara visual sebelum digunakan.

Omniscan: memiliki kepekaan 0,5 $\mathrm{mmol} / \mathrm{ml}$. Omniscan harus segera disimpan di tempat yang aman sebelum digunakan. Satu Botol hanya ditujukan untuk satu pasien atau di tujuan untuk sekali pakai saja. Omniscan di indikasikan pada orang dewasa dan anak-anak dari usia 6 bulan. Dosis total maksimum tidak boleh lebih dari $20 \mathrm{ml}$. harus dimulai segera setelah pemberian media kontras, tergantung pada urutan nadi yang digunakan dan protokol untuk pemeriksaan. Peningkatan optimal diamati dalam menit-menit pertama setelah injeksi (waktu tergantung pada jenis lesi/jaringan). Peningkatan umumnya berlangsung hingga 45 menit setelah injeksi medium kontras.

Di RSUD Dr. Saiful Anwar malang, menggunakan media kontras Gadovist karena terbukti paling aman digunakan dari pada jenis obat kontras yang lain.

\section{Efek pemberian kontras}

Jika pemberian kontras terlalu banyak maka akan mengendap. Sebelum melakukan MRI akan di tes kadar kreatininnya. Kadar kreatinin yang tinggi menandakan gangguan fungsi ginjal atau penyakit ginjal. .Jika kadar kreatininnya tinggi maka tidak bisa dilakukan kontras karena obat kontras tersebut tidak akan bisa dijadikan urin dan pada akhirnya juga akan mengendap. Adapun batas maksimal dari kadar kreatinin yaitu 1,5. Perbedaan gambar sebelum dan sesudah kontras ditunjukkan pada Gambar 5. 


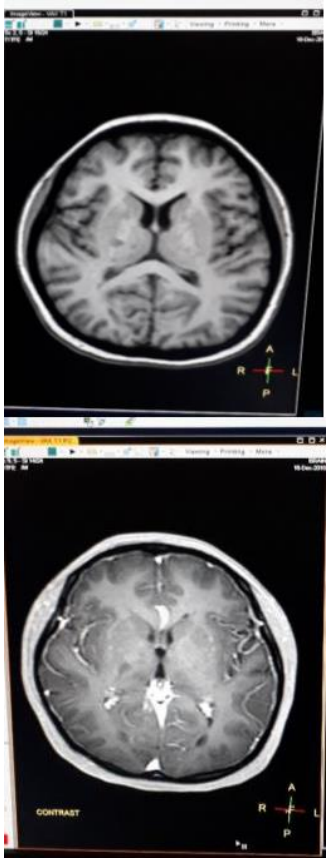

Gambar 5. Hasil foto sesudah dan sebelum diberi kontras

Ada beberapa hal yang perlu diperhatikan dalam kaitannya dengan kecelakaan selama pemeriksaan MRI. Bila terjadi keadaan gawat pada pasien, segera menghentikan pemeriksaan, pasien segera dikeluarkan dari pesawat MRI dengan menarik meja pemeriksaan dan segera berikan pertolongan dan apabila tindakan selanjutnya memerlukan alat medis yang bersifat ferromagnetik harus dilakukan di luar ruang pemeriksaan .

\section{Seandainya terjadi kebocoran} Helium, yang ditandai dengan bunyi alarm dari sensor oxigen, tekanlah EMERGENCY SWITCH dan segera membawa pasien ke luar ruang pemeriksaan serta buka pintu ruang pemeriksaan agar terjadi pertukaran udara, karena pada saat itu ruang pemeriksaan kekurangan oksigen.

Apabila terjadi pemadaman (Quenching), yaitu hilangnya sifat medan magnet yang kuat pada gentry (bagian dari pesawat MRI) secara tibatiba, tindakan yang perlu dilakukan buka pintu ruangan lebar- lebar agar terjadi pertukaran udara dan pasien segera di bawa keluar ruangan pemeriksaan. Hal perlu dilakukan karena Quenching menyebabkan terjadinya penguapan helium, sehingga ruang pemeriksaan MRI tercemar gas Helium. Selama pemeriksaan MRI untuk anak kecil atau bayi, sebaiknya ada keluarganya yang menunggu di dalam ruang pemeriksaan. Apabila ada pemadaman, data yang ada akan tersimpan dengan aman karena komputer memiliki UPS yang sangat besar sehingga mampu untuk backup komputer dan alat MRI sendiri sebelum akhirnya sebelum akhirnya di ganti oleh tenaga genset. Sehingga dalam beberapa menit, bisa memanfaatkan UPS untuk menyimpan data-data yang dibutuhkan.

\section{KESIMPULAN}

MRI (Magnetic Resonance Imaging) adalah sebuah alat diagnostic imejing tinggi yang menggunakan medan magnet, frekuensi radio tertentu 
Jurnal Biosains Pascasarjana Vol. 23 (2021) pp

(C) (2021) Sekolah Pascasarjana Universitas Airlangga, Indonesia

dan seperangkat computer untuk yang selanjutnya dapat digunakan menghasilkan gambar potongan- sebagai penentu apakah pasien tersebut potongan penampang tubuh manusia. memiliki kelainan (struktur abnormal). instrumen dari MRI terdiri dari bahan Kontras akan segera meningkat setelah non-magnetik diantaranya coil, hedset, di injeksi tergantung pada urutan pulsa bel, alat pemberi kontras, kursi roda, dan protokol yang digunakan. Biasanya ranjang pasien, alat anastesi.

Prinsip kerja MRI Bila tubuh pasien diposisikan dalam medan magnet yang kuat, inti-inti hidrogen tubuh akan searah dan berotasi mengelilingi arah/vektor medan magnet. Bila signal frekuensi radio dipancarkan melalui tubuh, beberapa inti hidrogen akan menyerap energi dari frekuensi radio tersebut dan mengubah arah, atau dengan kata lain mengadakan resonansi. Bila signal frekuensi radio dihentikan pancarannya, inti-inti tersebut akan kembali pada posisi semula, melepaskan energi yang telah diserap dan menimbulkan signal yang ditangkap oleh antena dan kemudian diproses computer dalam bentuk radiograf.

Kontras dapat digunakan sebagai pembeda SNR antara jaringan yang berdekatan. SNR ini dapat ditingkatkan dengan teknik pembobotan gambar (T1, T2, dan PD) atau kontras. Frekuensi RF non-resonansi dapat digunakan, untuk mendapatkan sinyal dari proton gratis. Kontras digunakan sebagai perbandingan antara T1 (anatomi) dan T2 (patologi) dapat di amati pada waktu maksimal 5 menit tergantung pada jenis lesi/jaringan.

\section{UCAPAN TERIMA KASIH}

Ucapan terimakasih pada RS Saiful Anwar Malang yang telah banyak memberikan kesempatan untuk pengambilan data.

\section{DAFTAR PUSTAKA}

Arifin Musthafa. 2011. Magnetic Resonance Imaging. (online) http://ipinfisikaui08.blogspot .com/2011/05/magneticresonance-imaging-mri.html. Diaksespada 27 Desember 2020 .

Astuti SD, Muzamil A dan Aisyiyah N, 2017, Analisis Kualitas Citra Tumor Otak Dengan Variasi Flip Angle (FA) menggunakan Sequence T2 Turbo Spin Echo Axial pada Magnetic Resonance Imaging (MRI), Prosiding Pertemuan Ilmiah Tahunan (PIT) Fisika Medis dan Biofisika Vol 1. no.1

Astuti SD., Astutik NVI dan Muzamil A, 2017, Optimalisasi Parameter Bandwidth 
Jurnal Biosains Pascasarjana Vol. 23 (2021) pp

(C) (2021) Sekolah Pascasarjana Universitas Airlangga, Indonesia

dan Time Echo untuk Mengurangi Susceptibility Artifacts dan

Chemical Shift pada MRI, Jurnal

Biosains Pascasarjana vol 19 no.3

Bahri Syaiful.Makalah MRI. (online)

https://www.academia.edu/2

0341172/MAKALAH_MRI.

Diaksespada 11 Januari

2020.

Blink Evert JBasic MRI Physics [Book].

$-2004$.

Ferry indriasmoko. 2009.

MengenalKontras MRI.

(online)

http://belajar-

mri.blogspot.com/2009/06/m

engenal-kontras-mri.html.

Diaksespada 30 Desember 2019

Mashari Ali Misri. 2010. Kontras MRI.

(online)

https://radiologitop.wordpres

s.com/2010/11/05/kontras-

mri/. Diaksespada 30

Desember 2019

Muzamil A, Astuti SA, Kamelia,

Suhariningsih, 2021, Fat

Suppression Spectral

Adiabatic Inversion

Recovery (SPAIR) to

Optimize the Quality of MRI

Pelvis Image, Mal J Med

Health Sci 17(SUPP2): 74-

77
Muzamil A, Indri NV, Astuti SD, Prijo

TA, 2018. Optimalisasi Citra

Axial Sequence T2 Gradient

Echo Dengan Variasi

Bandwidth Dan Time Echo

Pada MRI Shoulder Untuk

Mengurangi Susceptibility

Artifacts Dan Chemical

Shift, Journal of Health 5(2):

40-49

Podgorsack, Erwin B (2003) Review of Radiation Oncology Physics

: A Handbook for Teachers

and Students. International

Atomic Energy Agency,

Vienna, Austria.

R Ravichandran (2004). THE PHYSICS

OF RADIOLOGY AND

IMAGING.New Delhi,India.

Foreword.

Zuhriyah A, Muzzamil A, Astuti SD and

Suhariningsih, Determination

the Ischemic Stroke of Brain

MRI Based On Apparent

Diffusion Coefficient (ADC)

with $b$ Value Variation, PIT-

FMB \& SEACOMP 2019,

Journal of Physics:

Conference Series, 1505

(2020) 012061

doi:10.1088/1742-

6596/1505/1/012041 